\title{
Ergonomic work analysis of urban bus drivers in Rio de Janeiro city
}

\author{
Aloá Querido ${ }^{\mathrm{a},}$, Tainan Nogueira ${ }^{\mathrm{a}}$, Rafael Gama ${ }^{\mathrm{a}}$ and José Orlando ${ }^{\mathrm{a}}$ \\ ${ }^{a}$ Industrial Engineering Department, Federal University of Rio de Janeiro, Av. Athos da Silveira Ramos, 149 \\ block F, first floor, Rio de Janeiro, Brazil
}

\begin{abstract}
This article is the result of a case study on ergonomic work analysis carried out in an urban bus company located in Ilha do Governador, Rio de Janeiro. The methodology used in this work follows the French-tradition Ergonomic Analysis of the Work (EWA) combined with the best tradition from anglo-saxon ergonomic work analysis. The situated diagnosis was performed to provide relevant information about the work conditions of a bus driver.
\end{abstract}

Keyword: bus driver, double function, lombalgy, absenteeism, urban bus company

\section{Introduction}

This case study was carried out in an urban bus company of Ilha do Governador by students of Industrial Engineering Department who are from the Federal University of Rio de Janeiro. It focus on activities of bus drivers of line 326 which is the most critical regarding number of accidents, absenteeism, robbery and others.

This company has 484 employees, among them 311 are drivers. There are 132 vehicles distributed in 11 lines and a bus fleet for tourism and charter. The bad condition of urban bus system of Rio de Janeiro combined with cognitive pressure and bad work conditions in the company directly affect the health and the quality of life of the drivers.

The line 326 operates seven days a week, all day long. The timetables of drivers are divided in three shifts. Each driver must do three journeys a day.

\footnotetext{
*Corresponding author. E-mail: aloa.querido@poli.ufrj.br.
}

\section{Methodology}

The methodology used in this ergonomic action follows the French-tradition Ergonomic Analysis of the Work (Guerin et al.,1991). This method consists in several steps. First of all, it is identified the demand and the next steps are the respective reformulation, global analysis and the choice of critical work condition. A system of hypotheses is formulated to be validated or rejected through a systematic analysis. This dynamics validation-reconstruction leads the study field to a diagnosis with enough precision.

Moreover, this study was carried out with the sharp-end practitioners' approval from the beginning to the validations in a participative perspective.

\section{Preliminary studies}

Firstly, a global study was conducted in order to understand the activity of the bus drivers.

The driver must verify possible damage on the bus, check the number on turnstile and register it. After, he needs to do three journeys, control the turnstile and entrance and exit door, offer information 
about the itinerary when required by the passengers. Besides, he is a driver and also a cashier.

After several observations and inter-views with the employees, it was possible to identify the main issues involved in their work: thermal discomfort and complaints about double function

Lombalgy and gastroenteritis are the most common illness among the drivers of company. The stress is also frequent

Moreover, the bus company provided data related to absenteeism, accidents and robberies. The Figure 1, 2 and 3 were built from this data that represent a period of 12 months.

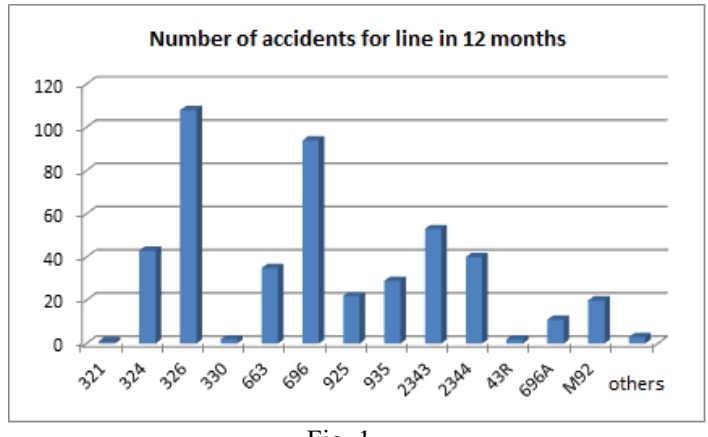

Fig. 1
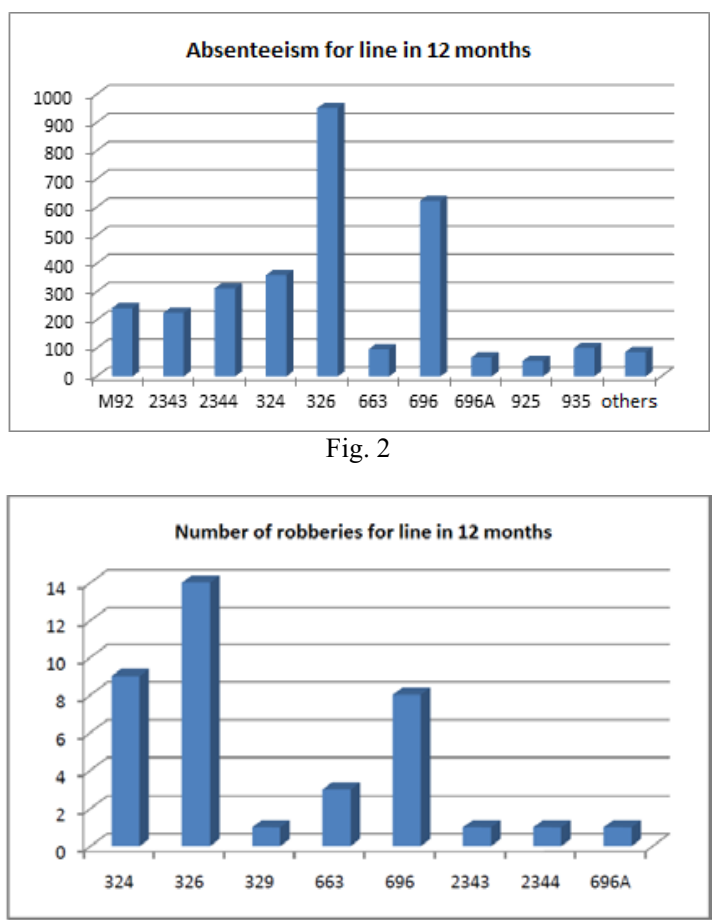

Fig. 3
From this information, the case study was focused on the most critical line 326.

\section{Demand reformulation}

Systematic observation was used to verify and identify the cause of the demands found out in the preliminary studies. Five journeys were made in different shifts and times: morning, afternoon, rush time and normal time. Interviews were also made.

Activity graphs were elaborated for all observations, containing several variables: postures, eye direction, communication and bus movement. In this way, it was possible to understand the activity developed by the driver.

The postures adopted by the bus drivers during working time are class 1 , according to the OWAS system considering that the seat is correctly adjusted. It was also possible to notice during the observations that the drivers need to give change while driving.

According to the drivers, they have 70 minutes to complete the journey, so it is almost impossible to give change with the bus stopped at the point. Videos and interviews revealed that the driver doesn't have full visibility of the traffic during rush time. It is not possible to see the right rearview mirror because of the people standing in the front of the bus.

The seat adjustment is broken in most of the vehicles of the company. The break between two journeys changes according to the time of the day. In rush times the break is, on average, three minutes.

\section{Diagnostic}

The studies revealed that the lack of seat's driver maintenance prevents the drivers adjust their seat in a proper way. This combined with the high vibration increases the impact on the spine. It is related to lombalgy, also known as back pain.

Due to the short break, the employees don't have enough time to eat or for other psychological needs. Consequently, they end up ingesting fatty foods, without nutrients and handled in inadequate hygienic conditions. This is associated with most of cases of gastroenteritis.

The heat is intense, especially in the front of the bus. The drivers are always using towels to dry the sweat. The activity also requires a lot of attention. Systematic observation pointed out high risks of accident because of the double function, especially 
when the bus is crowded. During rush times, people standing in the front of e bus affect directly the vision of the traffic.

The study showed that the high level of stress among drivers has many different causes: pressure of the company, enormous cognitive effort and intense traffic jams.

\section{Acknowledgments}

Prof. Jose O. Gomes was supported by a grant from CAPES Brazilian Research Foundation at the Cognitive Systems Engineering Lab of The Ohio State University.

\section{References}

[1] Crandall et ali, 2006. Working Minds. Cambridge, MIT Press,

[2] Guerin, F, et al. 2003. Compreender o trabalho para transformá-lo. São Paulo, Editora Edgard Blucher

[3] Itiro Iida. Ergonomia: Produto e Produção. São Paulo, Editora Edgard Blucher 